\title{
PREDIKSI TOTAL PADATAN TERLARUT BUAH MELON GOLDEN MENGGUNAKAN VIS-SWNIRS DAN ANALISIS MULTIVARIAT
}

\section{(PREDICTION OF TOTAL SOLUBLE SOLIDS OF GOLDEN MELON USING Vis-SWNIRS AND MULTIVARIATE ANALYSIS)}

\author{
Yuda Hadiwijaya $^{1 *}$, Kusumiyati ${ }^{1}$, dan Agus Arip Munawar ${ }^{2}$ \\ ${ }^{1}$ Fakultas Pertanian Universitas Padjadjaran \\ ${ }^{2}$ Fakultas Pertanian Universitas Syiah Kuala \\ ${ }^{1} J 1$. Raya Bandung Sumedang KM.21 Sumedang Jawa Barat 45363 \\ email: yuda09001@mail.unpad.ac.id
}

\begin{abstract}
Abstrak
Penelitian ini bertujuan untuk memprediksi total padatan terlarut buah melon golden (Cucumis melo L.) menggunakan Vis-SWNIRS dan analisis multivariat. Terdapat 82 sampel buah melon golden dipilih untuk dianalisis di Laboratorium Hortikultura, Fakultas Pertanian, Universitas Padjadjaran. Nirvana AG410 spectrometer dengan rentang panjang gelombang 300 sampai $1050 \mathrm{~nm}$ digunakan untuk pengambilan data spektra pada sampel buah melon utuh. Metode koreksi spektra yang digunakan yaitu Standard Normal Variate (SNV), Multiplicative Scatter Correction (MSC), dan Orthogonal Signal Correction (OSC). Pemodelan kalibrasi dilakukan menggunakan Partial Least Squares Regression (PLSR). Hasil penelitian menunjukkan bahwa penggunaan metode koreksi spektra OSC menampikan model kalibrasi terbaik dibandingkan spektra original dan 2 spektra lainnya yang telah dikoreksi. Koefisien determinasi pada spektra OSC memperlihatkan nilai R2 tertinggi yaitu 0,99. Di samping itu, nilai Ratio Performance To Deviation (RPD) yang diperoleh sebesar 3,40. Hal ini membuktikan total padatan terlarut buah melon golden dapat diprediksi dengan akurasi yang tinggi menggunakan Vis-SWNIRS dan analisis multivariat.
\end{abstract}

Kata kunci: melon golden, Vis-SWNIRS, analisis multivariat

\begin{abstract}
This study was aimed at predicting the total dissolved solids of golden melon (Cucumis melo L.) using Vis-SWNIRS and multivariate analysis. There were 82 golden melon fruit samples selected for analysis at the Horticulture Laboratory, Faculty of Agriculture, Padjadjaran University. Nirvana AG410 spectrometer with a wavelength range of 300 to $1050 \mathrm{~nm}$ was used to collect spectral data on intact melon fruit samples. The spectra correction methods used were Standard Normal Variate (SNV), Multiplicative Scatter Correction (MSC), and Orthogonal Signal Correction (OSC). Calibration modeling was carried out using Partial Least Squares Regression (PLSR). The results show that the use of the OSC spectra correction method presents the best calibration model compared to the original spectra and 2 other corrected spectra. The coefficient of determination on the OSC spectra shows the highest R2 value, namely 0.99 , besides that the ratio performance to deviation (RPD) value obtained is 3.40. This proves that the total dissolved solids of golden melon can be predicted with high accuracy using VisSWNIRS and multivariate analysis.
\end{abstract}

Keywords: golden melon, Vis-SWNIRS, multivariate analysis 


\section{PENDAHULUAN}

Buah melon merupakan komoditas yang banyak dikonsumsi oleh masyarakat karena rasanya yang enak, menyegarkan, dan mengandung berbagai manfaat bagi kesehatan tubuh manusia. Produksi buah melon di Indonesia mengalami peningkatan dari tahun ke tahun guna memenuhi permintaan konsumen. Total produksi buah melon pada tahun 2009 yaitu sebesar 85.861 ton, kemudian pada tahun 2014 meningkat menjadi 150.347 ton (Direktorat Jenderal Hortikultura, 2015). Berdasarkan data tersebut, terjadi peningkatan yang cukup tinggi dari tahun 2009 hingga 2014. Namun, peningkatan produksi melon di Indonesia belum diimbangi dengan monitoring kualitas yang baik.

Umumnya, penentuan grade buah melon berdasarkan tampilan fisik luarnya saja seperti warna kulit, ada tidaknya cacat fisik/luka, dan sebagainya. Akibatnya seringkali didapati buah melon yang tampilan fisiknya baik namun rasanya tidak sebaik tampilan fisiknya. Hal ini dikarenakan kualitas eksternal (fisik) tidak bisa dijadikan patokan untuk menentukan kualitas internal buah melon. Oleh karena itu diperlukan suatu metode nondestruktif yang dapat mengetahui kualitas internal buah melon, sehingga buah melon masih tetap dapat dipasarkan setelah dianalisis.

Near Infrared Spectroscopy (NIRS) merupakan salah satu teknologi pengukuran secara nondestruktif yang telah digunakan untuk mengontrol kualitas pada berbagai buah-buahan dan sayuran (Maniwara et al., 2014; Sánchez et al., 2012; Torres, PérezMarín, De la Haba, \& Sánchez, 2015; Vitale et al., 2013). Kemunculan teknologi NIRS juga didorong oleh ekspektasi konsumen yang tinggi akan kualitas buah dan sayuran salah satunya yaitu total padatan terlarut yang sering diartikan sebagai tingkat kemanisan dari suatu produk.

Banyak penelitian yang dilakukan untuk memprediksi kualitas internal buah tanpa merusak bagian permukaan. Namun, NIRS paling menarik bagi para peneliti untuk mengembangkannya lebih lanjut. NIRS memiliki berbagai kelebihan di antaranya pengukurannya cepat, tanpa menggunakan bahan kimia, dan ramah lingkungan (Blanco \& Villarroya, 2002). Selain itu, dalam sekali pengujian dapat diperoleh banyak parameter kualitas sekaligus.

Teknik NIRS didasarkan pada pengukuran cahaya dengan berbagai panjang gelombang yang dicerahkan pada sampel. Bahan organik yang tercerahkan oleh cahaya inframerah akan mengalami vibrasi pada ikatan atom $\mathrm{O}-\mathrm{H}, \mathrm{C}-\mathrm{H}$, dan N-H. Cahaya tersebut dapat dipantulkan, diserap, ditransmisikan, atau dihamburkan oleh sampel. Kemudian, cahaya pantulan dari sampel dikumpulkan oleh detektor dan ditransformasikan ke dalam sebuah 
spektrum yang selanjutnya akan tersimpan pada spektrometer.

Tiap jenis buah-buahan memiliki karakteristik dan senyawa berbeda-beda yang terkandung di dalamnya sehingga spektrum yang diperoleh dari hasil pengukuran cahayanya akan berbeda-beda pula (Kusumiyati, Hadiwijaya, Putri, \& Mubarok, 2019). Visible-Short Wavelength Near Infrared Spectroscopy (Vis-SWNIRS) merupakan penggunaan radiasi visible-near infrared pada panjang gelombang 300-1050 $\mathrm{nm}$ untuk memperoleh informasi mengenai kandungan kimia pada bahan organik.

Total padatan terlarut (TPT) merupakan kandungan bahan yang larut air seperti glukosa, sukrosa, fruktosa, dan pektin. TPT seringkali dijadikan indikator kemanisan pada buah. Informasi mengenai tingkat kemanisan buah merupakan hal yang penting untuk diketahui terutama pada buah melon golden, karena hal ini berkaitan dengan penerimaan konsumen terhadap produk tersebut. Berbagai penelitian tentang penggunaan Vis-SWNIRS untuk memprediksi total padatan terlarut buah telah dilakukan pada sawo (Kusumiyati et al., 2018), pisang (Zude, 2003), apel (Pissard et al., 2012), murbei hitam (Soltanikazemi et al., 2017), jeruk (Jamshidi, Minaei, Mohajerani, \& Ghassemian, 2012), jambu (Kusumiyati et al., 2020).

Analisis multivariat diperlukan untuk menerjemahkan spektrum-spektrum hasil pemindaian data spektra pada buah melon golden melalui pemodelan kalibrasi sehingga akan diperoleh nilai prediksi parameter kualitas sampel, dalam hal ini yaitu TPT. Penelitian ini bertujuan untuk memprediksi kandungan TPT buah melon golden menggunakan Vis-SWNIRS dan analisis multivariat. Sebagai tambahan, pada penelitian ini diaplikasikan beberapa metode koreksi spektra dengan tujuan memperoleh model kalibrasi terbaik untuk memprediksi TPT buah melon golden.

\section{METODE PENELITIAN}

Penanaman melon golden dilakukan di Kebun Hidroponik, Fakultas Pertanian, Universitas Padjadjaran. Tanaman melon ditanam di dalam screen house pada ketinggian tempat yang berkisar $750 \mathrm{mdpl}$. Kultivar melon golden yang digunakan yaitu Mekarsari SH-1. Sampel buah melon dipanen sebanyak 82 sampel untuk dilakukan analisis di Laboratorium Hortikultura, Fakultas Pertanian, Universitas Padjadjaran.

Instrumen Vis-SWNIRS yang digunakan adalah Nirvana AG410 yang memiliki rentang panjang gelombang 300-1050 $\mathrm{nm}$ dengan interval $3 \mathrm{~nm}$. Pengambilan data spektra dilakukan pada sampel buah melon utuh. Masing-masing sampel buah melon diradiasi sebanyak enam kali yang mewakili bagian pangkal, tengah, dan ujung buah. Data spektra yang diambil merupakan 
spektra absorbency. Setelah pengambilan data spektra selesai dilakukan, sampel buah melon didestruksi. Air saripati hasil parutan sampel buah melon diukur menggunakan refraktometer (Atago, Japan) untuk memperoleh nilai total padatan terlarut yang diekspresikan dengan nilai \% Brix. Sebelum dilakukan pemodelan kalibrasi, data spektra terlebih dahulu dikoreksi dengan tujuan untuk mengurangi efek noise pada spektra sehingga diperoleh suatu model kalibrasi yang dapat lebih diandalkan.

Standard normal variate (SNV) merupakan salah satu metode koreksi spektra yang banyak digunakan untuk memperbaiki spektra. SNV bertujuan mengurangi efek hamburan akibat pengambilan data spektra. Multiplicative scatter correction (MSC) digunakan untuk mengoreksi keragaman spektra yang diakibatkan oleh pengaruh multiplikatif. Orthogonal signal correction (OSC) adalah metode koreksi spektra yang baru-baru ini dikembangkan. OSC memperbaiki matriks data $\mathrm{X}$ (data spektra) dengan membuang informasi pada spektra yang secara ortogonal tidak berkorelasi dengan matriks data $\mathrm{Y}$ (parameter kualitas yang diinginkan). Penggunaan ketiga metode koreksi spektra ini diharapkan dapat meningkatkan keakuratan model kalibrasi dibandingkan dengan spektra original.

Partial least squares regression (PLSR) merupakan metode kalibrasi yang paling sering digunakan untuk menginterpretasikan data spektra. PLSR menggunakan variabel X (data spektra) dan Y (parameter kualitas yang diinginkan) untuk mengembangkan model kalibrasi untuk menemukan variabel laten (tersembunyi) pada $\mathrm{X}$ yang dapat memprediksi variabel laten pada $Y$.

Validasi dilakukan untuk menguji kemampuan model kalibrasi untuk mem-prediksi sampel yang baru. Validasi silang berguna untuk menghindari overfitting yang mengakibatkan model kalibrasi gagal untuk memprediksi sampel yang baru. Metode validasi silang yang digunakan pada penelitian ini adalah $K$-Fold Cross Validation. Keseluruhan sampel secara acak dibagi ke dalam 20 segment. Masingmasing segment terdiri atas 4-5 sampel. Dua puluhsegmenttersebutdikelompokkanmenjadi 19 segment sebagai train set dan 1 segment sebagai test set. Sembilanbelas segment pada train set digunakan untuk memprediksi test set. Model kalibrasi dievaluasi menggunakan validasi silang dan koefisien determinasi $\left(\mathrm{R}^{2}\right)$, root mean squares error of calibration (RMSEC), root mean squares error of cross validation (RMSECV), dan ratio performance to deviation (RPD).

\section{HASIL DAN PEMBAHASAN}

Pada teknik spektroskopi Vis-SWNIR, data spektra yang diperoleh dari sampel tidak hanya berisi informasi mengenai kandungan kimia pada sampel, namun mengandung 
pula informasi latarbelakang (background information) dan noise (Cen \& He, 2007). Koreksi spektra dapat mengurangi keragaman spektra akibat emisi cahaya dan nonlinieritas (Rinnan, Van Den Berg, \& Engelsen, 2009). Oleh karena itu, diperlukan koreksi spektra untuk meningkatkan akurasi dari model kalibrasi (Kusumiyati et al., 2019). Metode koreksi spektra SNV, MSC, dan OSC masing-masing diaplikasikan pada spektra original (Gambar 1) Metode SNV mereduksi efek pembauran yang terdapat pada spektra original dengan menetapkan skala spektrum individual tanpa memerlukan spektrum referensi. Penerapan metode koreksi spektra SNV mengurangi sebagian besar variasi pada spektra original (Gambar 1b). Pada dasarnya, SNV mengubah offset ke nilai 0 , kemudian menstandarisasi nilai rata-rata spektrum. Hasil koreksi spektra dengan metode SNV menunjukkan rentang nilai absorbance kira-kira dari -2 hingga 2. Metode MSC mengoreksi masing-masing spektrum berdasarkan spektrum rujukannya dengan memanfaatkan hasil perhitungan regresi linier sederhana. sehingga keragaman data akibat dari emisi cahaya dapat direduksi. Metode koreksi spektra MSC umumnya menampilkan hasil yang mirip dengan metode SNV. Namun, metode MSC (Gambar 1c) tidak mengubah rentang nilai absorbance dari data spektra original (Gambar 1a). Metode koreksi spektra OSC
(Gambar 1d) mengoreksi spektra original berdasarkan data referensi (nilai referensi TPT) dengan mereduksi variabel-variabel yang tidak berkorelasi dengan data referensi. Hal ini dilakukan untuk menghindari hilangnya informasi penting saat pemodelan kalibrasi (Cen \& He, 2007).

Pengukuran nilai Total Padatan Terlarut (TPT) menggunakan refraktometer bertujuan untuk mengukur total gula secara kasar. Dengan asumsi semakin tinggi nilai TPT buah melon, semakin tinggi pula tingkat kemanisan buah melon tersebut. Sebagai tambahan, nilai TPT biasanya dijadikan indikator tingkat kematangan, rasa pada buah dan sayuran untuk membantu dalam mengatur waktu panen, penjualan, dan pengolahan.

Pada dasarnya TPT merupakan gula (sukrosa dan fruktosa) dan berbagai senyawa lainnya seperti asam organik, asam amino larut, lemak, mineral, dan lain-lain. Refraktometer mengukur TPT berdasarkan indeks biasnya. Nilai indeks bias diperoleh dari kecepatan cahaya pada ruang hampa dibandingkan dengan ketika cahaya menembus sampel. Ketika cahaya menembus sampel, kecepatannya akan berkurang. Hal ini dikarenakan adanya padatan terlarut yang terdapat pada sampel tersebut. Semakin tinggi konsentrasi padatan terlarut sampel, semakin tinggi pula indeks biasnya. Hal tersebut juga berlaku sebaliknya. Nilai TPT 
Jurnal Penelitian Saintek, Vol. 25, Nomor 2, 2020

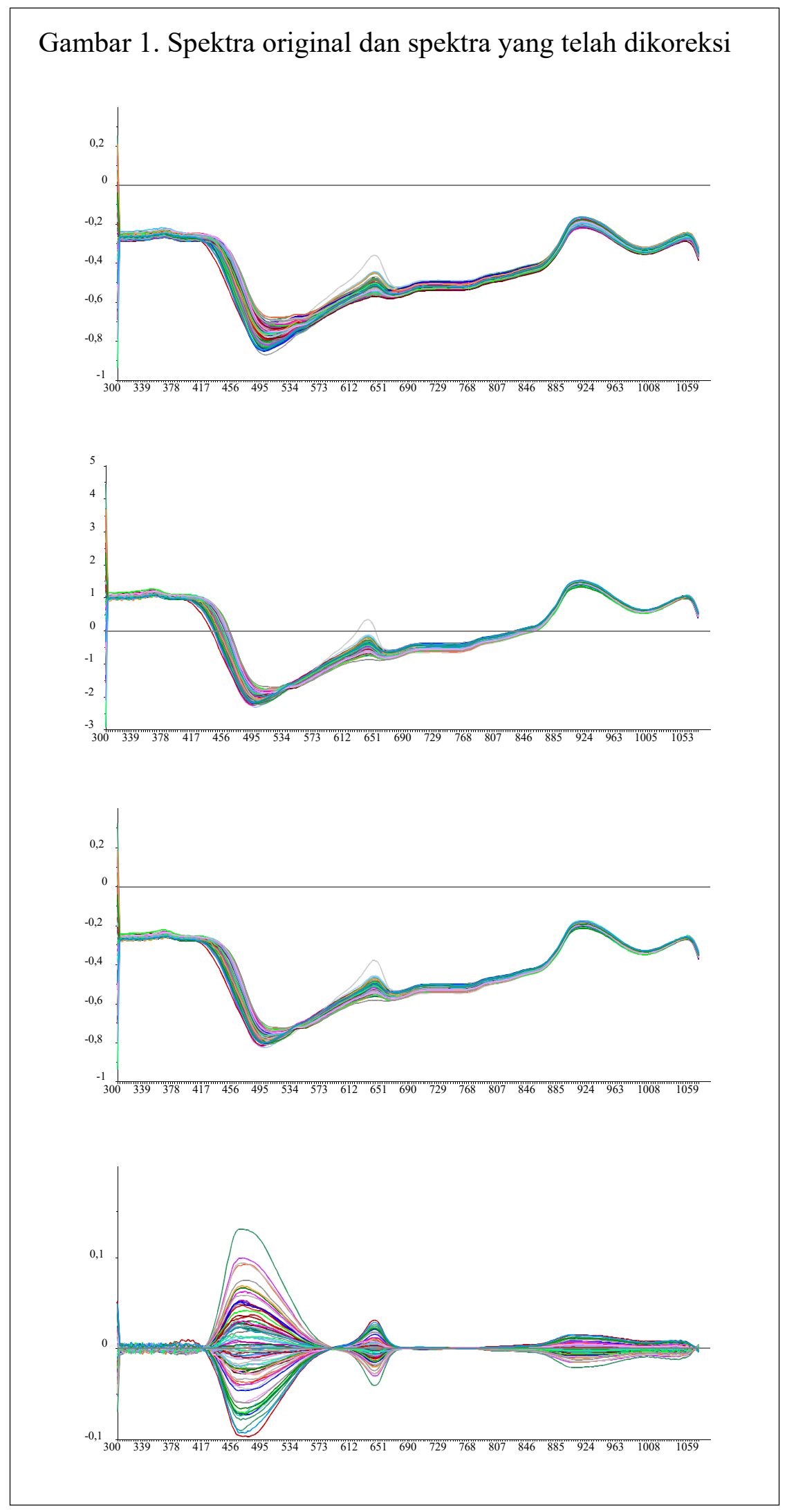

108 
buah melon golden kultivar Mekarsari SH-1 yang diperoleh pada penelitian ini berkisar antara 3,95-12,4\% Brix (Tabel 1).

Tabel 1

Hasil Pengukuran Total Padatan Terlarut

\begin{tabular}{ccccc}
\hline $\begin{array}{c}\text { Jumlah } \\
\text { Sampel }\end{array}$ & Min. & Maks. & Rerata & $\begin{array}{c}\text { Standar } \\
\text { Deviasi }\end{array}$ \\
\hline 82 & 3,95 & 12,4 & 8,35 & 1,78 \\
\hline
\end{tabular}

Pemodelan kalibrasi pada teknik spektroskopi Vis-SWNIR melibatkan data spektra sampel dan data referensi yang merupakan hasil pengujian lab. Metode regresi yang digunakan yaitu PLSR dengan tujuan untuk menguji linieritas antara nilai dugaan TPT berdasarkan spektra VisSWNIR dan nilai referensi TPT. Koreksi pada spektra original berfungsi untuk mendapatkan linieritas terbaik antara kedua matriks tersebut. PLSR merupakan metode kalibrasi multivariat yang dapat menangani masalah multikolinieritas. Metode regresi PLSR dapat menentukan jumlah faktor yang optimal tanpa menyebabkan overfitting pada model kalibrasi (Sharabian et al., 2014). Penggunaan regresi PLSR dan Vis-SWNIR menghasilkan nilai koefisien korelasi sebesar 0,85 untuk pendugaan nilai TPT pada buah tomat (Huang et al., 2018).

Gambar 2 menunjukkan model kalibrasi dan validasi TPT pada spektra original dan OSC. Garis regresi dan titiktitik berwarna biru menunjukkan regresi dan sebaran data untuk model kalibrasi yang telah dibuat, sedangkan yang berwarna merah merupakan hasil validasi silang dari model kalibrasi. Sumbu x menampilkan data referensi hasil pengukuran nilai TPT menggunakan refraktometer, sedangkan sumbu y menerangkan nilai TPT prediksi Vis-SWNIRS. Dari keempat model kalibrasi yang telah dibangun, model kalibrasi dari spektra OSC menampilkan sebaran data yang paling dekat dengan garis regresi dibandingkan dengan ketiga model kalibrasi lainnya. Semakin dekat titik-titik sebaran data dengan garis regresi, maka semakin kuat hubungan linier antara data referensi dan nilai prediksi TPT buah melon golden. Sebaliknya, semakin jauh dengan garis regresi, maka semakin lemah pula hubungan liniernya. Jarak antara garis regresi dan titik-titik sebaran data dihitung sebagai nilai error.

Nilai koefisien determinasi model kalibrasi tertinggi diperoleh pada koreksi spektra dengan metode OSC yaitu sebesar 0,99 dan nilai validasi sebesar 0,91 (Tabel 2). Selain itu, nilai RMSEC dan RMSECV metode OSC mendapatkan nilai terendah yaitu sebesar 0,16 dan 0,48 . Semakin kecil nilai error yang diperoleh, semakin baik model kalibrasi yang telah dibangun. Nilai RPD dari spektra OSC tercatat sebagai nilai tertinggi sebesar 3,40 disusul dengan spektra MSC, SNV, dan original. Nicolaï et al. (2007) menjelaskan 
Gambar 2. Model kalibrasi dan validasi TPT pada spektra original dan OSC
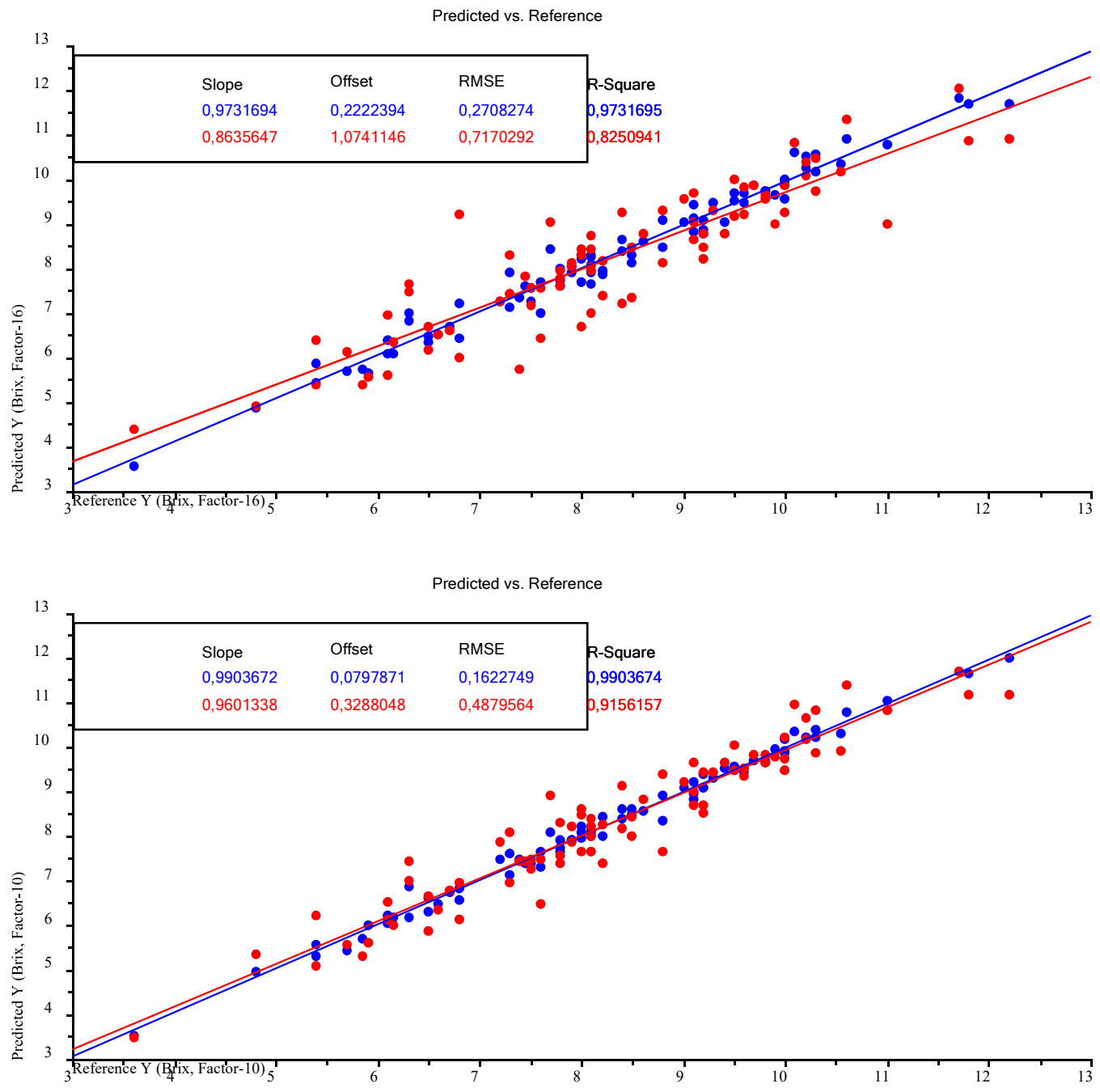

Tabel 2

Evaluasi Model Kalibrasi dan Validasi TPT Buah Melon Golden pada Spektra Original dan 3 Spektra Yang Telah Dikoreksi

\begin{tabular}{ccccccc}
\hline Spektra & Faktor & Kalibrasi $\left(\mathrm{R}^{2}\right)$ & Validasi $\left(\mathrm{R}^{2}\right)$ & RMSEC & RMSECV & RPD \\
\hline Original & 16 & 0,97 & 0,82 & 0,27 & 0,71 & 2,32 \\
SNV & 16 & 0,96 & 0,82 & 0,30 & 0,70 & 2,36 \\
MSC & 16 & 0,96 & 0,84 & 0,28 & 0,67 & 2,45 \\
OSC & 10 & 0,99 & 0,91 & 0,16 & 0,48 & 3,40 \\
\hline
\end{tabular}

bahwa dengan nilai RPD di atas 3,0 mengindikasikan model kalibrasi tersebut memiliki kemampuan prediksi yang sangat baik. Pada penelitian lain, Saad et al. (2014) 
menggunakan Vis-SWNIR dan metode koreksi spektra OSC untuk memprediksi TPT pada tomat, nilai $\mathrm{R}^{2}$ model kalibrasi yang diperoleh sebesar 0,99 dibandingkan spektra original yang hanya memperoleh nilai $\mathrm{R}^{2}$ sebesar 0,89 . Hal ini sejalan dengan penelitian Gardana et al. (2018) yang menyimpulkan bahwa koreksi pada spektra original dapat meningkatkan linieritas pada model kalibrasi.

Explained variance menjelaskan seberapa besar variasi dari variabel $\mathrm{Y}$ yang dapat dijelaskan oleh variabel $\mathrm{X}$ pada suatu faktor tertentu (Gambar 3). Garis berwarna

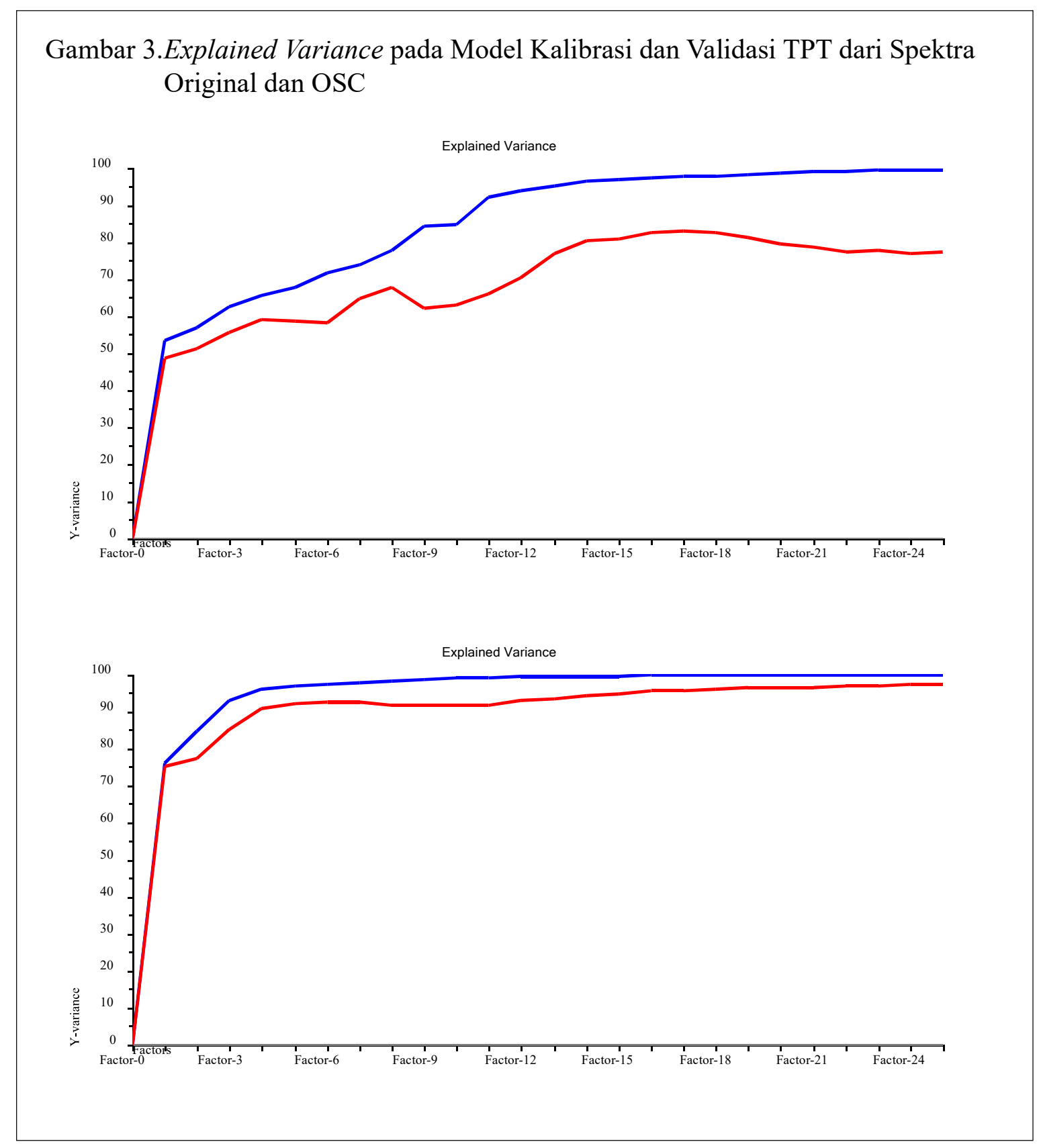


biru merupakan explained variance pada model kalibrasi, sedangkan yang berwarna merah yaitu validasi. Semakin tinggi nilai explained variance pada suatu model kalibrasi, maka semakin baik pula linieritas model kalibrasi tersebut. Model kalibrasi yang diharapkan yaitu memiliki nilai explained variance yang tinggi dengan jumlah faktor yang rendah. Menurut Jankovská \& Šustová (2003) jumlah faktor yang tinggi mendefinisikan tingginya gangguan pada spektra tersebut. Berdasarkan Gambar 3 dapat disimpulkan bahwa penggunaan metode koreksi spektra OSC (3b) mampu mereduksi jumlah faktor pada variabel $\mathrm{X}$ dan memperoleh nilai explained variance yang tinggi. Pada spektra OSC, nilai linieritas sebesar $99 \%(0,99)$ dapat dicapai dengan jumlah faktor sebanyak 10 . Namun, pada spektra original dengan jumlah faktor sebanyak 16 hanya memperoleh nilai linieritas sebesar $97 \%(0,97)$. Berdasarkan beberapa evaluasi model kalibrasi yang telah dilakukan, penggunaan metode koreksi spektra OSC memperlihatkan performa terbaik dalam memprediksi TPT pada buah melon golden.

\section{SIMPULAN}

Hasil penelitian menampilkan bahwa Vis-SWNIRS dan analisis multivariat dapat memprediksi TPT buah melon golden dengan nilai akurasi yang tinggi. Metode koreksi spektra yang diaplikasikan pada penelitian ini memberikan pengaruh terhadap model kalibrasi yang diperoleh. Model kalibrasi terbaik ditunjukkan pada spektra yang dikoreksi menggunakan metode OSC dengan nilai $\mathrm{R}^{2}$ kalibrasi, validasi, RMSEC, RMSECV, dan RPD berturut-turut sebesar $0,99,0,91,0,16,0,48$, dan 3,40 .

\section{DAFTAR PUSTAKA}

Blanco, M., \& Villarroya, I. (2002). NIR spectroscopy: A rapid-response analytical tool. TrAC - Trends in Analytical Chemistry, 21(4), 240-250. https://doi. org/10.1016/S0165-9936(02)00404-1.

Cen, H., \& He, Y. (2007). Theory and application of near infrared reflectance spectroscopy in determination of food quality. Trends in Food Science \& Technology, 18(2), 72-83. https://doi. org/10.1016/j.tifs.2006.09.003.

Direktorat Jenderal Hortikultura. (2015). Statistik produksi hortikultura tahun 2014. Diunduh dari http://www. hortikultura.pertanian.go.id

Gardana, C., Scialpi, A., Fachechi, C., \& Simonetti, P. (2018). Near-infrared spectroscopy and chemometrics for the routine detection of bilberry extract adulteration and quantitative determination of the anthocyanins. Journal of Spectroscopy, 1-8. https:// doi.org/10.1155/2018/4751247

Huang, Y., Lu, R., \& Chen, K. (2018). Assessment of tomato soluble solids content and $\mathrm{pH}$ by spatially-resolved and conventional Vis/NIR spectroscopy. Journal of Food Engineering, 236(3), 19-28. https://doi.org/https://doi.org/ 10.1016/j.jfoodeng.2018.05.008.

Jamshidi, B., Minaei, S., Mohajerani, E., \& Ghassemian, H. (2012). Reflectance vis/ 
NIR spectroscopy for nondestructive taste characterization of Valencia oranges. Computers and Electronics in Agriculture, 85, 64-69. https://doi. org/10.1016/j.compag.2012.03.008

Jankovská, R., \& Šustová, K. (2003). Analysis of cow milk by near-infrared spectroscopy. Czech Journal of Food Sciences, 21(4), 123-128. https://doi. org/10.17221/3488-cjfs

Kusumiyati, Hadiwijaya, Y., \& Putri, I. E. (2019). Non-destructive classification of fruits based on vis-NIR spectroscopy and principal component analysis. Jurnal Biodjati, 4(1), 89-95. https:// doi.org/10.15575/biodjati.v4i1.4389

Kusumiyati, Hadiwijaya, Y., Putri, I. E., \& Mubarok, S. (2019). Water content prediction of crystal guava using visible-near infrared spectroscopy and chemometrics approach. IOP Conference Series: Earth and Environmental Science. https://doi. org/10.1088/1755-1315/393/1/012099.

Kusumiyati, Hadiwijaya, Y., Putri, I. E., Mubarok, S., \& Hamdani, J. S. (2020, February). Rapid and non-destructive prediction of total soluble solids of guava fruits at various storage periods using handheld near-infrared instrument. IOP Conference Series: Earth and Environmental Science, 458(1), p. 012022. https://doi.org/10.1088/17551315/458/1/012022.

Kusumiyati, Mubarok, S., Hamdani, J. S., Farida., Sutari, W., Hadiwijaya, Y., Putri, I. E., \& Mutiarawati, T. (2018). Evaluation of sapodilla fruit quality using near-infrared spectroscopy. Journal of Food, Agriculture and Environment, 16(1), 49-53.

Maniwara, P., Nakano, K., Boonyakiat, D., Ohashi, S., Hiroi, M., \& Tohyama, T. (2014). The use of visible and near infrared spectroscopy for evaluating passion fruit postharvest quality. Journal of Food Engineering, 143, 3343. https://doi.org/10.1016/j.jfoodeng. 2014.06.028.

Nicolaï, B. M., Beullens, K., Bobelyn, E., Peirs, A., Saeys, W., Theron, K. I., \& Lammertyn, J. (2007). Nondestructive measurement of fruit and vegetable quality by means of NIR spectroscopy: A review. Postharvest Biology and Technology, 46(2), 99-118. https://doi. org/10.1016/j.postharvbio.2007.06.024

Pissard, A., Baeten, V., Romnée, J. M., Dupont, P., Mouteau, A., \& Lateur, M. (2012). Classical and NIR measurements of the quality and nutritional parameters of apples: A methodological study of intra-fruit variability. Biotechnology, Agronomy and Society and Environment, 16(3), 294-306.

Rinnan, Å., Van Den Berg, F., \& Engelsen, S. B. (2009). Review of the most common pre-processing techniques for nearinfrared spectra. Trends in Analytical Chemistry, 28(10), 1201-1222. https:// doi.org/10.1016/J.TRAC.2009.07.007.

Saad, A. G., Jaiswal, P., \& Jha, S. N. (2014). Non-destructive quality evaluation of intact tomato using VIS-NIR spectroscopy. International Journal of Advanced Research, 2(12), 632-639.

Sánchez, M. T., De La Haba, M. J., Benítez-López, M., FernándezNovales, J., Garrido-Varo, A., \& PérezMarín, D. (2012). Non-destructive characterization and quality control of intact strawberries based on NIR spectral data. Journal of Food Engineering, 110(1), 102-108. https://doi.org/ 10.1016/j.jfoodeng.2011.12.003.

Sharabian, V. R., Noguchi, N., \& Ishi, K. (2014). Significant wavelengths for prediction of winter wheat growth status and grain yield using multivariate analysis. Engineering in 
Agriculture, Environment and Food, 7(1), 14-21. https://doi.org/10.1016/j. eaef.2013.12.003

Soltanikazemi, M., Mehdizadeh, S. A., \& Heydari, M. (2017). Non-destructive evaluation of the internal fruit quality of black mulberry (Morus nigra L.) using visible-infrared spectroscopy and genetic algorithm. International Journal of Food Properties, 20(11), 2437-2447. https://doi.org/10.1080/10 942912.2016.1238930

Torres, I., Pérez-Marín, D., De la Haba, M. J., \& Sánchez, M. T. (2015). Fast and accurate quality assessment of Raf tomatoes using NIRS technology.
Postharvest Biology and Technology, 107, 9-15. https://doi.org/10.1016/j. postharvbio.2015.04.004

Vitale, R., Bevilacqua, M., Bucci, R., Magrì, A. D., Magrì, A. L., \& Marini, F. (2013). A rapid and non-invasive method for authenticating the origin of pistachio samples by NIR spectroscopy and chemometrics. Chemometrics and Intelligent Laboratory Systems, 121, 90-99. https://doi.org/10.1016/j. chemolab.2012.11.019

Zude, M. (2003). Non-destructive prediction of banana fruit quality using VIS/NIR spectroscopy. Fruits, 58(3), 135-142. https://doi.org/10.1051/fruits:2003001. 